\begin{tabular}{l} 
SOSAINS \\
JURNAL \\
JURAL SOSIAL DAN SAINS \\
P-ISSN 2774-7018, E-ISSN 2774-700X \\
EFEKTIVITAS DOSIS PUPUK KANDANG TERHADAP PERTUMBUHAN \\
DAN HASIL TANAMAN KANGKUNG \\
Ermansyah ${ }^{1}$ dan Nana Ariska ${ }^{2}$ \\
1,2 Fakultas Pertanian, Universitas Teuku Umar, Indonesia \\
Corresponding Author :Ermansyah ${ }^{1}$ \\
Erifayansyah@ gmail.com dan Nariska@ @mail.com \\
Disetujui : 05 Februari 2022 $\quad$ Dipublikasikan : 15 Februari 2022 \\
\hline $\begin{array}{l}\text { Info Artikel : } \\
\text { Diterima : 17 Januari 2022 }\end{array}$
\end{tabular}

\begin{abstract}
ABSTRAK
Kata Kunci: Kangkung, Pertumbuhan, Pupuk Kandang

Latar Belakang : Kangkung merupakan salah satu sayuran yang populer dan di gemari masyarakat indonesia.Tanaman ini dapat ditanam di dataran rendah dan dataran tinggi. Kangkung merupakan jenis tanaman sayuran daun, termasuk kedalam famili Convolvulaceae. Tujuan : Tujuan Penelitian ini untuk mengetahui sejauh mana efektifitas pemberian pupuk kandang terhadap pertumbuhan dan hasil tanaman kangkung Metode : Penelitian ini akan dilaksanakan di desa Babul makmur, kec.simeulue barat. Waktu pelaksanaan Penelitian ini di mulai pada bulan November 2021 sampai dengan selesai. Bahan-bahan yang digunakan dalam penelitian ini antara lain : tanah tanam, pupuk organik kotoran sapi, pupuk Urea (Kandungan $46 \% \mathrm{~N}$ ), benih Kangkung darat. Sedangkan alat yang digunakan, antara lain : cangkul, cetok, pisau, tree pembenihan, polybag (ukuran media $5 \mathrm{~kg}$ ), label, alat pengukur penggaris, alat tulis, alat ukur berat (timbangan house dan timbangan elektrik). Hasil : Hasil penelitian menunjukan bahwa terdapat pengaruh yang sangat nyata terhadap tinggi tanaman, jumlah daun, berat basah per tanaman dan berat basah tanaman per polybagpada tanaman Kangkung akibat pemberian pupuk organik kotoran sapi. Kesimpulan : Perlakuan pemberian dosis pupuk kandang 50 ton/Ha menghasilkan pertumbuhan dan hasil maksimum, sedangkan untuk pertumbuhan dan hasil yang optimum (tepat guna danmenguntungkan) terhadap tanaman Kangkung Darat, ditunjukkan perlakuan pemberiandosis pupuk kotoran sapi 30 ton/Ha.
\end{abstract}

\title{
ABSTRACT
}

Background: Kangkung is one of the popular vegetables and enjoyed by the people of

Keywords: Kale, Growth, Manure
Indonesia. This plant can be grown in the lowlands and highlands. Kangkung is a type of leaf vegetable plant, belonging to the Convolvulaceae family. Purpose : The purpose of this study was to determine the effectiveness of manure application on the growth and yield of kale. Method: This research will be carried out in Babul prosperous village, west Simeulue district. The implementation time of this research starts in November 2021 until it is finished. The materials used in this study include: planting soil, organic cow dung fertilizer, urea fertilizer (46\% $N$ content), land kangkung seeds. While the tools used, among others: hoe, trowel, knife, seedling tree, polybag (medium size $5 \mathrm{~kg}$ ), labels, measuring tools ruler, stationery, weight measuring instruments (house scales and electric scales). Results : The results showed that there was a very significant effect on plant height, number of leaves, wet weight per plant and plant wet weight per polybag 


\section{Efektivitas Dosis Pupuk Kandang Terhadap 2022 Pertumbuhan dan Hasil Tanaman Kangkung}

on Kangkung plants due to organic cow dung fertilizer. Conclusion : The treatment with 50 tons/ha of manure gave maximum growth and yields, while for optimum growth and yields (effective and profitable) for Kangkung Darat, it was shown that the dose of cow dung fertilizer was 30 tons/ha.

\section{PENDAHULUAN}

Kangkung merupakan salah satu sayuran yang populer dan di gemari masyarakat indonesia. Tanaman ini dapat ditanam di dataran rendah dan dataran tinggi. Kangkung merupakan jenis tanaman sayuran daun, termasuk kedalam famili Convolvulaceae (Nurliana, Noviyanti, \& Azwir, 2017). Daun kangkung panjang, berwarna hijau keputihputihan merupakan sumber pro-vit A yang sangat baik. Berdasarkan tempat tumbuh, kangkung dibedakan menjadi dua yaitu kangkung kering atau tegalan, dan kangkung air, hidup ditempat yang berair dan basah. Tanaman ini dapat tumbuh baik di daerah tropis (Iswanto \& Astuti, 2019). Saat ini banyak di budidayakan kangkung darat, karena masyarakat lebih berminat pada jenis kangkung tersebut. Hasil tanaman kangkung ini dijual dalam bentuk cabutan tanaman dengan akarnya. Tanaman ini termasuk tanaman dikotil dan berakar tunggang.

Kangkung merupakan tanaman yang memiliki banyak manfaat. Tanaman ini bergizi tinggi dan lengkap, seperti kalori, protein, lemak, karbohidrat, serat, kalsium, posfor, zat besi, natrium, kalium, vitamin A,vitamin B, vitamin $\mathrm{C}$, karoten, hentriakontan dan sitosterol (Putra, 2020). Senyawa kangkung yang dikandung dalam tanaman kangkung adalah saponin, flavonoid dan poliferol yang dapat digunakan untuk pengobatan bagi penderita susah tidur (Jayavarman, 2021). Serat pada kangkung sangat baik untuk mencegah konstipasi sehingga dapat menghalangi terjadinya kanker perut. Karetenoid dalam tubuh akan diubah menjadi vitamin A serta klorofil tinggi, kedua senyawa ini berperan sebagai antioksidan yang berguna untuk mencegah penuaan dan menghalangi mutasi genetik penyebab kanker (Ngapu, Raka, \& Hanum, 2020).

Budidaya kangkung sangat mudah, karena sayuran ini bersiklus panen cepat dan relatif tahan hama (Prasetio, 2015). Karena itulah, harga kangkung di pasaran relatif murah dibanding jenis sayuran yang lain. Pada umumnya, penanaman kangkung hanya sebagai tanaman budidaya yang dikelola sendiri untuk kebutuhan idup sehari \pm hari. Tetapi karena adanya kebutuhan sayuran di pasaran maka tanaman kangkung menjadi salah satu sayuran yang banyak dicari oleh konsumen (Setyaningrum \& Saparinto, 2012). Dalam rangka meninkatkan produktifitas tanaman kangkung diperlukan berbagai upaya ke arah peningkatan produksi secara berkelanjutan dan kualitas panen tanaman akan dijual di pasaran. Salah satu upaya tersebut adalah melalui intensifikasi tanaman dengan cara pemberian pupuk organik (Purwantini, 2016).

Bahan organik, pupuk kandang atau kompos merupakan bagian penting dalam sistem tanah. Peran utama kompos adalah sebagai "conditioner" tanah-tanah kritis, memperbaiki sifat fisik dan biologik tanah dan menambah unsur hara (Yulina \& Ambarsari, 2021). Bahan organik memiliki peran penting di tanah karena membantu menahan air, sehingga ketersediaan air tanah lebih terjaga, membantu memegang ion sehingga meningkatkan kapasitas tukar ion atau ketersediaan hara (Agustina, Jumini, \& Nurhayati, 2015). Menambah hara terutama N, P, dan K setelah bahan organik terdekomposisi sempurna, membantu granulasi tanah sehingga tanah menjadi lebih gembur atau remah, yang akan memperbaiki aerasi tanah dean perkembangan sistem perakaran, serta memacu pertumbuhan mikroba dan hewan tanah lainnya yang sangat membantu proses dekomposisi bahan organik tanah. 
Karakter beberapa jenis bahan organik saling berbeda, dilihat dari persentase Corganik, N-total, Nanorganik, pH dan KTK-nya. Keasaman $(\mathrm{pH})$ bahan tersebut berkisar antara 5,9-6,8 (sisa tumbuhan), 5,2-9,4 (kotoran hewan). Kotoran lembu memiliki pH sekitar 5,2 sedangkan pH kotoran kuda mencapai 9,4. Berdasar kecepatan pelepasan CO2, laju mineralisai atau dekomposisi kotoran kuda paling lambat dibanding kotoran babi, ayam dan lembu (Rahayu, 2020). Namun demikian laju dekomposisi kotoran hewan relatif lebih cepat dibanding dengan sisa tumbuhan. Kenyataan ini penting dipertimbangan dalam pemilihan pupuk dari kotoran hewan.

Pada penelitian ini peneliti menggunakan pupuk kandang sapi sebagai bahan dasar pupuk untuk digunakan pada sayuran kangkung dan diaplikasikan dengan perbedaan konsentrasi untuk mengetahui pengaruh pemberian pupuk kandang terhadap produksi sayuran kangkung. Penelitian ini bertujuan untuk mengetahui tingkat Efektivitas Dosis Pupuk Kandang Terhadap Pertumbuhan Dan Hasil Tanaman Kangkung.

\section{METODE PENELITIAN}

Penelitian ini akan dilaksanakan di desa Babul makmur,kec.simeulue barat. Waktu pelaksanaan Penelitian ini di mulai pada bulan November 2021 sampai dengan selesai. Bahan-bahan yang digunakan dalam penelitian ini antara lain : tanah tanam, pupuk organik kotoran sapi, pupuk Urea (Kandungan $46 \% \mathrm{~N}$ ), benih Kangkung darat. Sedangkan alat yang digunakan, antara lain : cangkul, cetok, pisau, tree pembenihan, polybag (ukuran media $5 \mathrm{~kg}$ ), label, alat pengukur penggaris, alat tulis, alat ukur berat (timbangan house dan timbangan elektrik).

Penelitian ini menggunakan Rancangan Acak Kelompok (RAK) sederhana yang terdiri dari enam (6) perlakuan dengan tiga (3) ulangan dan untuk pengamatan, masingmasing perlakuan diwakili dua (2) tanaman sampel, kemudian untuk penempatan perlakuan pada petak percobaan dilakukan secara acak. Adapun perlakuan-perlakuan Pupuk Kandang terdiri dari enam (6) dosis, antara lain :

$\mathrm{P} 0=$ Tanpa Pupuk Organik (kontrol)

$\mathrm{P} 1=$ Pupuk Organik 10 ton/Ha (10 gram/tanaman atau 100 gram/polybag)

$\mathrm{P} 2=$ Pupuk Organik 20 ton/Ha (20 gram/tanaman atau 200 gram/polybag $)$

$\mathrm{P} 3$ = Pupuk Organik 30 ton/Ha (30 gram/tanaman atau 300 gram/polybag)

$\mathrm{P} 4=$ Pupuk Organik 40 ton/Ha (40 gram/tanaman atau 400 gram/polybag)

$\mathrm{P} 5=$ Pupuk Organik 50 ton/Ha (50 gram/tanaman atau 500 gram/polybag).

Untuk mengetahui adanya pengaruh pemberian pupuk Organik terhadap pertumbuhan dan hasil Tanaman Kangkung, maka digunakan Uji F dengan taraf 5\%, yaitu Uji Analisis Sidik Ragam (ASR). Apabila dari hasil Uji F 5\% terdapat pengaruh yang nyata, maka dilanjutkan dengan Uji $\mathrm{T}$ (Uji Beda Nyata Terkecil) dengan taraf 5\% guna mengetahui perbedaan diantara dosis perlakuan pupuk Organik, sehingga dapat diketahui dosis perlakuan yang tepat guna (dosis efektif) dan menguntungkan (dosis efisien).

Macam variabel pengamatan pertumbuhan dan hasil Tanaman Kangkung yang diamati pada penelitian ini meliputi: Tinggi Tanaman, Jumlah Daun, Berat Basah per Tanaman dan Berat Basah Tanaman per Polybag.

\section{HASIL DAN PEMBAHASAN}

Hasil analisis ragam menunjukkan bahwa perlakuan pupuk kandang berpengaruh nyata $(\mathrm{P}<0,05)$ terhadap tinggi tanaman, jumlah daun, dan luas daun bayam. Hasil analisis ragam menunjukkan, bahwa perlakuan pemberian dosis pupuk kandang berpengaruh sangat nyata pada pengamatan tinggi tanaman selama pertumbuhan tanaman 


\section{Efektivitas Dosis Pupuk Kandang Terhadap Pertumbuhan dan Hasil Tanaman Kangkung}

kangkung darat, yaitu pada saat tanaman umur 10 hari, 20 hari dan 30 hari setelah tanam (Kogoya, Dharma, \& Sutedja, 2018).

Pada Tabel 1. menunjukkan, bahwa dengan meningkatnya pemberian dosis pupuk kandang akan diikuti pula dengan peningkatan tinggi tanaman selama pertumbuhan tanaman kangkung darat. Tinggi tanaman, terpendek (terkecil) cenderung ditunjukkan perlakuan tanpa pupuk organik $(21,89 \mathrm{~cm})$ dan secara statistik berbeda nyata dengan perlakuan pemberian dosis pupuk organik kotoran sapi lainnya. Tanaman tertinggi cenderung dicapai perlakuan pemberian dosis pupuk kandang 50 ton/Ha $(30,67 \mathrm{~cm})$, meskipun secara statistik tidak berbeda nyata dengan perlakuan pemberian dosis pupuk kandang 40 ton/Ha $(29,64 \mathrm{~cm})$, dan perlakuan pemberian dosis pupuk kandang 30 ton/ $\mathrm{Ha}$ $(28,89 \mathrm{~cm})$, tetapi ketiga perlakuantersebut berbeda nyata secara statistik dengan perlakuan pemberian dosis pupuk kandang yang lainnya.

Tabel 1.

Rata-rata Tinggi Tanaman (cm) Kangkung Pemberian Pupuk Kandang pada Berbagai Dosis dan Umur Pengamatan.

\begin{tabular}{|c|c|c|c|}
\hline \multirow{2}{*}{$\begin{array}{l}\text { Perlakuan Pemberian Dosis } \\
\text { Pupuk kandang }\end{array}$} & \multicolumn{3}{|c|}{$\begin{array}{l}\text { Rata-Rata Tinggi Tanaman } \\
(\mathrm{cm})\end{array}$} \\
\hline & 10 hari & 20 hari & 30 hari \\
\hline P0 $=$ Tanpa Pupuk Kandang & $6,82 \mathrm{a}$ & $16,35 \mathrm{a}$ & $22,89 \mathrm{a}$ \\
\hline $\mathrm{P} 1=$ Pupuk kandang 10 ton/Ha & $8,64 \mathrm{~b}$ & $17,89 \mathrm{~b}$ & $24,17 \mathrm{~b}$ \\
\hline $\mathrm{P} 2=$ Pupuk kandang 20 ton/Ha & $10,23 \mathrm{c}$ & $19,17 \mathrm{~b}$ & $27,33 \mathrm{~b}$ \\
\hline P3 = Pupuk kandang 30 ton/Ha & $11,89 \mathrm{~d}$ & $21,33 \mathrm{c}$ & $29,89 \mathrm{c}$ \\
\hline P4 = Pupuk kandang 40 ton $/ \mathrm{Ha}$ & $12,35 \mathrm{~d}$ & $22,72 \mathrm{~cd}$ & $30,14 \mathrm{c}$ \\
\hline P5 = Pupuk kandang 50 ton $/ \mathrm{Ha}$ & $12,64 \mathrm{~d}$ & $23,43 \mathrm{~d}$ & $30,17 \mathrm{c}$ \\
\hline BNT $5 \%$ & 0 & 1, & 2, \\
\hline
\end{tabular}

Keterangan : Angka-angka yang didampingi huruf yang sama pada kolom yang sama tidak berbeda nyata pada Uji BNT 5\%.

Hasil analisis ragam menunjukkan, bahwa perlakuan pemberian dosis pupuk kandang berpengaruh sangat nyata pada pengamatan jumlah daun selama pertumbuhan tanaman kangkung darat, baik pada saat tanaman ber- umur 10 hari, 20 hari dan 30 hari setelah tanam.

Tabel 2.

Rata-rata Jumlah Daun Tanaman Kangkung Pemberian Pupuk Kandang pada Berbagai Dosis dan Umur Pengamatan.

\begin{tabular}{|c|c|c|c|}
\hline \multirow{2}{*}{$\begin{array}{c}\text { Perlakuan Pemberian Dosis Pupuk } \\
\text { kandang }\end{array}$} & \multicolumn{3}{|c|}{$\begin{array}{c}\text { Rata-Rata Jumlah Daun Tanaman } \\
\text { Kangkung }\end{array}$} \\
\hline & 10 hari & 20 hari & 30 hari \\
\hline $\mathrm{P} 0=$ Tanpa Pupuk Kandang & $4,50 \mathrm{a}$ & $5,25 \mathrm{a}$ & $8,25 \mathrm{a}$ \\
\hline $\mathrm{P} 1=$ Pupuk kandang 10 ton $/ \mathrm{Ha}$ & $500 \mathrm{~b}$ & $6,25 \mathrm{~b}$ & $10,75 \mathrm{~b}$ \\
\hline $\mathrm{P} 2=$ Pupuk kandang 20 ton $/ \mathrm{Ha}$ & $5,25 \mathrm{~b}$ & $6,50 \mathrm{~b}$ & $11,50 \mathrm{~b}$ \\
\hline $\mathrm{P} 3=$ Pupuk kandang 30 ton $/ \mathrm{Ha}$ & $5,85 \mathrm{c}$ & $7,50 \mathrm{c}$ & $13,00 \mathrm{c}$ \\
\hline $\mathrm{P} 4=$ Pupuk kandang 40 ton $/ \mathrm{Ha}$ & $5,12 \mathrm{c}$ & $7,75 \mathrm{c}$ & $13,75 \mathrm{c}$ \\
\hline $\mathrm{P} 5=$ Pupuk kandang 50 ton $/ \mathrm{Ha}$ & $5,10 \mathrm{c}$ & $8,25 \mathrm{c}$ & $14,00 \mathrm{c}$ \\
\hline BNT $5 \%$ & 0 , & 0 , & 1 , \\
\hline
\end{tabular}


Keterangan : Angka-angka yang didampingi huruf yang sama pada kolom yang sama tidak berbeda nyata pada Uji BNT 5\%.

Pada Tabel 2. menunjukkan, bahwa dengan meningkatnya pemberian dosis pupuk kandang akan diikuti pula dengan peningkatan jumlah daun selama pertumbuhan tanaman Kangkung Darat. Jumlah daun terkecil cenderung ditunjukkan perlakuan tanpa pupuk kandang $(8,25$ helai) dan secara statistik berbeda nyata dengan perlakuan pemberian dosis pupuk organik kotoran sapi lainnya. Jumlah daun terbanyak cenderung dicapai perlakuan pemberian dosis pupuk kandang 50 ton/Ha (14,00 helai), meskipun secara statistik tidak berbeda nyata dengan perlakuan pemberian dosis pupuk kandang 40 ton/Ha (13,75 helai), dan perlakuan pemberian pupuk kandang 30 ton/Ha (13,00 helai), tetapi ketiga perlakuan dosis pupuk tersebut berbeda nyata secara statistik dengan perlakuan pemberian dosis pupuk kandang lainnya.

Hasil analisis ragam menunjukkan, bahwa perlakuan pemberian dosis pupuk kandang berpengaruh sangat nyata pada pengamatan berat basah per tanaman dan berat basah tanaman per polybag. Pada Tabel 2. menunjukkan, bahwa dengan meningkatnya pemberian dosis pupuk kandang akan diikuti pula dengan peningkatan berat basah per tanaman dan berat basah tanaman per polybag tanaman kangkung darat. Berat basah per tanaman dan berat basah tanaman per polybag terkecil cenderung ditunjukkan perlakuan tanpa pupuk kandang (10,30 gram dan 127,43 gram) dan secara statistik berbeda nyata dengan perlakuan pemberian dosis pupuk organik kotoran sapi lainnya. Jumlah daun terbanyak cenderung dicapai perlakuan pemberian dosis pupuk kandang 50 ton/ $\mathrm{Ha}(23,20$ gram dan 241,80 gram), meskipun secara statistik tidak berbeda nyata dengan perlakuan pemberian dosis pupuk kandang 40 ton/Ha (22,70 gram dan 237,93 gram), dan perlakuan pemberian pupuk kandang 30 ton/Ha (21,90 gram dan 229,10 gram), tetapi ketiga perlakuan dosis pupuk tersebut berbeda nyata secara statistik dengan perlakuan pemberian dosis pupuk kandang lainnya.

Tabel 3.

Rata-rata Berat Basah per Tanaman dan Berat Basah Tanaman per Polybag (gram) Tanaman Kangkung Akibat Pengaruh Pemberian Dosis Pupuk kandang.

\begin{tabular}{ccc}
\hline & \multicolumn{2}{c}{ Rata-Rata Berat Basah (gram) Tanaman } \\
Perlakuan Pemberian Dosis & \multicolumn{2}{c}{ Kangkung } \\
\cline { 2 - 3 } Pupuk & Per Tanaman & Per Polybag \\
P0 & $10,30 \mathrm{a}$ & $129,43 \mathrm{a}$ \\
P1 = Panpa Pupuk Kandang & $15,70 \mathrm{~b}$ & $176,20 \mathrm{~b}$ \\
P2 = Pupuk kandang 10 ton/Ha 20 ton/Ha & $17,10 \mathrm{~b}$ & $195,66 \mathrm{~b}$ \\
P3 = Pupuk kandang 30 ton/Ha & $21,90 \mathrm{c}$ & $227,11 \mathrm{c}$ \\
P4 = Pupuk kandang 40 ton/Ha & $22,70 \mathrm{c}$ & $237,93 \mathrm{c}$ \\
P5 = Pupuk kandang 50 ton/Ha & $23,20 \mathrm{c}$ & $241,80 \mathrm{c}$ \\
\hline BNT 5\% & 2, & 19,86 \\
\hline
\end{tabular}

Keterangan : Angka-angka yang didampingi huruf yang sama pada kolom yang sama tidak berbeda nyata pada Uji BNT 5\%. 


\section{KESIMPULAN}

Berdasarkan hasil pengamatan dan pembahasan dari penelitian pengaruh pemberian dosis pupuk kandang terhadap pertumbuhan dan hasil tanaman Kangkung dapat disimpulkan sebagai berikut, terdapat pengaruh yang sangat nyata pada variabel pengamatan tinggi tanaman, jumlah daun dan berat basah per tanaman serta berat basah tanaman per polybag tanaman Kangkung akibat pemberian pupuk organik kotoran sapi. Perlakuan pemberian dosis pupuk kandang 50 ton/Ha menghasilkan pertumbuhan dan hasil maksimum, sedangkan untuk pertumbuhan dan hasil yang optimum (tepat guna dan menguntungkan) terhadap tanaman Kangkung, ditunjukkan perlakuan pemberian dosis pupuk kandang 30 ton/Ha.

\section{BIBLIOGRAFI}

Agustina, Agustina, Jumini, Jumini, \& Nurhayati, Nurhayati. (2015). Pengaruh Jenis Bahan Organik Terhadap Pertumbuhan Dan Hasil Dua Varietas Tomat (Lycopersicum esculentum Mill L.). Jurnal Floratek, 10(1), 46-53.

Iswanto, Nova, \& Astuti, Puji. (2019). The influence of Cow Manure and Liquid Organic fertilizer Super Natural Nutrition towart growth and yield of land cress (Ipomoea reptans Poir). Agrifor: Jurnal Ilmu Pertanian dan Kehutanan, 18(1), 135-144.

Jayavarman, Mathein. (2021). Pengaruh perbandingan kecepatan aliran air dan variasi konsentrasi nutrisi pertumbuhan tanaman (Kangkung) pada sistem irigasi hidroponik NFT. Malang: Universitas Islam Negeri Maulana Malik Ibrahim.

Kogoya, Tina, Dharma, I. Putu, \& Sutedja, I. Nyoman. (2018). Pengaruh pemberian dosis pupuk urea terhadap pertumbuhan tanaman bayam cabut putih (Amaranthus tricolor L.). E-Jurnal Agroekoteknologi Tropika, 7(4), 575-584.

Ngapu, Albinus, Raka, I. Dewa Nyoman, \& Hanum, Farida. (2020). Pengaruh Perlakuan Kosentrasi Biourine Sapi Terhadap Pertumbuhan Dan Hasil Tanaman Kangkung Darat (Ipomoea reptans Poir). AGRIMETA: Jurnal Pertanian Berbasis Keseimbangan Ekosistem, 10(19), 27-31.

Nurliana, Nurliana, Noviyanti, Anita, \& Azwir, Azwir. (2017). Identifikasi Tanaman Sayuran di Desa Cot Yang Aceh Besar. Serambi Saintia: Jurnal Sains Dan Aplikasi, 5(1).

Prasetio, Untung. (2015). Panen sayuran hidroponik setiap hari. Jakarta: AgroMedia.

Purwantini, Tri Bastuti. (2016). Potensi dan prospek pemanfaatan lahan pekarangan untuk mendukung ketahanan pangan. Forum Penelitian Agro Ekonomi, 30(1), 13-30.

Putra, A. R. (2020). Pengaruh Metode Dan Dosis Aplikasi Vermikompos Pada Budidaya Tanaman Kangkung (Ipomoea Reptans Poir) Secara Hidroganik.

Rahayu, Dewi. (2020). Pengaruh pemberian pupuk kandang kotoran sapi pada media tanam tanah, pasir dan serbuk kayu terhadap pertumbuhan tanaman cabai rawit (Capsicum Frutescens l.). Surabaya: UIN Sunan Ampel Surabaya.

Setyaningrum, Hesti Dwi, \& Saparinto, Cahyo. (2012). Panen sayur secara rutin di lahan sempit. Penebar Swadaya Grup.

Yulina, Henly, \& Ambarsari, Wiwik. (2021). Hubungan Kadar Air Dan Bobot Isi Tanah Terhadap Berat Panen Tanaman Pakcoy Pada Kombinasi Kompos Sampah Kota Dan Pupuk Kandang Sapi. Agro Tatanen| Jurnal Ilmiah Pertanian, 3(2), 1-6. 
Volume 2, Nomor 2, Februari 2022

p-ISSN 2774-7018; e-ISSN 2774-700X
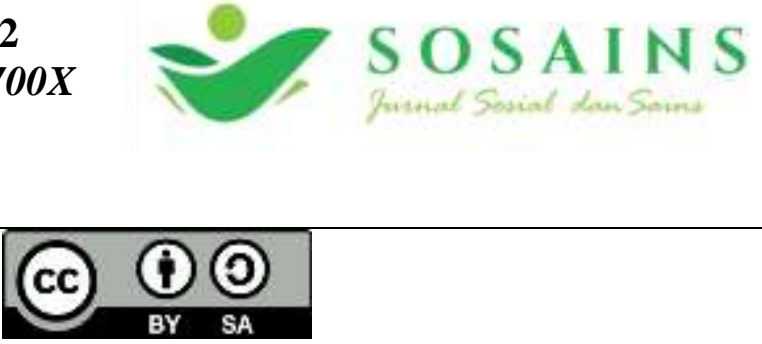

This work is licensed under a Creative Commons Attribution-ShareAlike 4.0 International License. 